\title{
Върху разпространението на ларингеалния карцином във Варненския район
}

\author{
Д. Марев \\ Клиника по оториноларингология при УМБАЛ "Св. Марина" - Варна
}

\begin{abstract}
The malignant new formations with ENT localisation have a lesser incidence than the other ones in this country. The larynx ranks first in the incidence of damages and according to a number of authors it comprises $1-3 \%$ of all malignant tumor.

The morbidity from cancer of the larynx in the region of Varna is high: $11.6 \mathrm{o} / 0000$ for the year 2002, $9.5 \mathrm{o} / 0000$ for 2006 as compared to $7.6 \%$ oooo for 2007.

There is also high incidence of laryngeal cancer in the active age in the age groups 51-60 and 41-50.

Cancer of the larynx affects mainly males. 174 patients were observed for 2002 of which 169 and 24 out of a total of 25 newly detected.

The urban population is more commonly affected than the rural areas. Out of all the observed patients 133 live in towns. 16 out of the 25 newly detected come from the urban areas.

Cancer of the epipharynx ranks second in incidence followed by the cancer of the orolarynx, hypopharynx, nose and perinasal cavities.
\end{abstract}

Резюме

Злокачествените новообразувания с ЛОР-локализация имат по-малко разпространение от останалите в нашата страна. Първо място по честота на поражение заема ларинксьт, който по данни на редица автори е $1-3 \%$ от всички злокачествени тумори.

Заболеваемостта от рак на ларинкса във Варненския район е висока: 11,6 о/о0оо 2002 г.; 9.5 о/оооо за 2006 г. в сравнение с тази за страната -7.6 o/о0оо за 2007 год.

Най-засегнати са възрастовите групи при 41-50 и 51-60 год.

Ракът на ларинкса засяга изключително мъжете. От 174 за наблюдение през 2002 год. 169 са мъже, а от новооткритите -24 от общо 25 .

Населението от града боледува по-често от това в селата. От всички наблюдавани 133 живеят в града. От 25 новооткрити 16 са от града.

На второ място по разпространение е карциномът на епифаринкса, следван от този на орофаринкса, хипофаринкса, носа и околоносните кухини.
$\Pi$ о литературни данни заболеваемостта от рак на ларинкса е $1-3 \%$ от всички злокачествени тумори $(1,2,3)$. По статистически данни се среща най-често на 40-60-годишна възраст, като боледуват повече мъжете. Редица автори сочат като етиологичен момент тютюнопушенето, злоупотребата с алкохол, хронични възпаления на гръкляна и др.

Липсата на системни проучвания за заболеваемостта, болестността и смъртността от рак на гръкляна в нашия район определи целта на нашето проучване: да се проследят заболеваемостта, болестността и смъртността от кариином на гръкляна за периода 2002-2007 год.

За същия период в УНГ-клиниката и Онкологичния диспансер - Варна са постыпили за изследване и лечение 206 болни с карцином на ларинкса, от които 198 мъже и 8 жени. Те представляват $79.23 \%$ от всички ракови заболявания на ЛОР-органите. Останалите $20.77 \%$ са злокачествени тумори на епифаринкса, тонзилите, синусите и ушите.

Разпределението на болните по възрастови групи с карцином на ларинкса е представено на таблица № 1 :

\begin{tabular}{|c|c|r|r|r|r|r|r|}
\hline $\begin{array}{c}\text { Възраст } \\
\text { пол }\end{array}$ & $31-40$ & $41-50$ & $51-60$ & $61-70$ & $71-80$ & $\begin{array}{c}\text { Над } \\
80\end{array}$ & всичко \\
\hline $\begin{array}{c}\text { Мъже } \\
\text { Жени }\end{array}$ & 15 & 52 & $\begin{array}{r}70 \\
1\end{array}$ & $\begin{array}{r}39 \\
1\end{array}$ & $\begin{array}{r}17 \\
0\end{array}$ & $\begin{array}{r}5 \\
0\end{array}$ & $\begin{array}{r}198 \\
8\end{array}$ \\
\hline всичко & 16 & 58 & 70 & 40 & 17 & 5 & 206 \\
\hline
\end{tabular}

От изнесените данни се вижда, че повече от $50 \%$ от болните, заболели от рак на ларинкса, са на възраст над 50 год. 
От проведеното проучване установихме, че въпреки значителния брой болни с ларингеален карцином в младата възраст, той остава типично заболяване за мъжете в напреднала възраст. Забелязва се тенденция за повишаване на болестността във възрастовата група 41-50 год. Ракът на ларинкса засяга изключително мъжете $(5,6)$.

Заболеваемостта от рак на ларинкса при градското и селско население показва значителна разлика в "полза на първите" $(7,8)$. За този период ние установихме 121 болни от градското и 85 от селското население. Заболеваемостта при градското е 1.9 на 100000 население, а при селското 0.2 на 100000 население. От анамнезата се установи, че значителна част от градските жители са работили в селското стопанство като механизатори, трактористи, шофьори и др. Около $40 \%$ от заболелите градски жители са работили във вредна среда: запрашеност, влага, вредни газове повече от 10 год. Съвременната индустриализация, химизация и урбанизация рязко повишиха нивото на карциногените в биосферата. Според данни на С3О 75\% от раковите заболявания са професионално обусловени.

При анализа на заболеваемостта и болестността на Варненския район ние установихме, че през 2004 год. са водени на диспансерен отчет 174 болни, от които 169 мъже. От новооткритите 25.24 на 100000 население са мъже. Заболеваемостта от рак на ларинкса е 9.68 на 100000 население, а болестността 19.4 на 100000 население. За същата година заболеваемостта в Република България е 4.6, а болестността 26.9 на 100000 население. Тези данни съвпадат с проучванията на $(4,9)$.

Ние установихме, че се наблюдава непрекъснато увеличение на заболеваемостта от ларингеален карцином за нашата област, като новорегистрираните болни се увеличават. Считаме, че това се дължи на подобрената диагностика. Заболеваемостта от ларингеален карцином за Варненския район е значително по-висока, почти два пъти над средната за страната. Съществуват литературни данни, които дават основание да се мисли, че развитието на едно злокачествено заболяване е резултат на различни въшни въздействия, съчетани с генетична кодировка в организма (5).

Данните за смъртността от рак на ларинкса за този период показват тенденция за стабилизиране. Ние установихме незначително намаление ежегодно с 0.001 на 100000 население. Тези резултати са найдобре изразени при мъжете, при които тя намалява значително. Същото се наблюдава и при жените. Подобно явление ние обясняваме с диагностиката на карцинома в ранен стадий и своевременно ефективно приложено лечение.

От нашето проучване установихме, че при болните с ларингеален карцином доминира глотисната локализация с тенденция за зачестяване на супраглотисната. Хистопатологичното изследване показва най-често диференциран спиноцелуларен карцином 69.9\%.

Ранното откриване на карцинома е от първостепенно значение (9) за избора на лечение, постигане на оперативна радикалност чрез частични резекции на ларинкса без съществени функционални нарушения.

Въз основа на изложеното можем да направим следните изводи:

1. За изследвания период ние установихме, че ракът на ларинкса е $72.23 \%$ от всички онкозаболявания на ЛОР-органите.

2. На най-голям риск са изложени лицата над 50 години, като заболеваемостта нараства още от 40-годишна възраст.

3. Заболеваемостта от ларингелен карцином при населението за нашия район показва тенденция за доближаване.

4. Болестността при рака на ларинкса е с тенденция за увеличаване.

5. Смъртността от рак на ларинкса показва стациониране на показателите.

6. Необходимо е задълбочено епидемиологично проучване, за да се установят някои зависимости между работата, работната среда и заболеваемостта при тази локализация.
Литература:

1. Бойкикев, Св., Р. Райчев. Тумори на горните въздухоносни пътища., С, МФ, 149-217, 1979, 2.

2. Бойкикев, Св., Онкология (информационен бюлетин), 16, 1976.

3. Маламов М., Г. Георгиев. Лечение на туморите на ушите, носа и гърлото. С., МФ, 1983.

4. Габровски Р., М. Милков. Качество на живота при пациенти с авансирали карциноми на УНГ, провели ускорено лъчелечение. Българска оториноларингология. Том 2, 2003, брой 2, 11-14.

5. Габровски Р., М. Милков. Далечни метастази при пациенти с авансирали карциноми на УНГ, провели радикално лъчелечение. Българсака оториноларингология, Том 2, брой 3, 21-25.
6. Berenberg W, Neuhauser EB. Cardio-esophageal relaxation (achalasia) as a cause of vomiting in infants Ca larynx. Pediatrics 1999; 5: 414-20.

7. Cherry J, Margulies SI. Contact ulcer of the Ca larynx. Laryngoscope 1968; 78: 1937-40.

8. Delahunty JE, Cherry J. Experimentally produced vocal cord granulomas. Laryngoscope 2001; 78: 1941-7.

9. Delahunty JE. Ca laryngx. J Laryngol Otol 2000; 86: 335-42.

10. Chodosh PL. Gastro-esophago-pharyngeal reflux. Laryngoscope 2001; 87: 1418-27.

11. Goldberg M, Noyek AM, Pritzker KP. Laryngeal granuloma secondary to gastro-esophageal reflux. J Otolaryngol 2002; 7: 196-202. 